\title{
Profibrotic Signaling and HCC Risk during Chronic Viral Hepatitis: Biomarker Development
}

\author{
Alessia Virzì ${ }^{1,2}\left(\mathbb{D}\right.$, Victor Gonzalez-Motos ${ }^{1,2}$, Simona Tripon ${ }^{1,2,3}$, Thomas F. Baumert $1,2,3,4$ (D) \\ and Joachim Lupberger $1,2, * \mathbb{D}$ \\ 1 Université de Strasbourg, 67000 Strasbourg, France; virzi@unistra.fr (A.V.); \\ gonzalezmotos@unistra.fr (V.G.-M.); simona.tripon@chru-strasbourg.fr (S.T.); \\ thomas.baumert@unistra.fr (T.F.B.) \\ 2 Institut National de la Santé et de la Recherche Médicale, U1110, Institut de Recherche sur les Maladies \\ Virales et Hépatiques (IVH), 67000 Strasbourg, France \\ 3 Institut Hospitalo-Universitaire, Pôle Hépato-Digestif, Nouvel Hôpital Civil, 67091 Strasbourg, France \\ 4 Institut Universitaire de France (IUF), 75231 Paris, France \\ * Correspondence: joachim.lupberger@unistra.fr
}

check for updates

Citation: Virzì, A.; Gonzalez-Motos, V.; Tripon, S.; Baumert, T.F.; Lupberger, J. Profibrotic Signaling and HCC Risk during Chronic Viral Hepatitis: Biomarker Development. J. Clin. Med. 2021, 10, 977. https://doi.org/ $10.3390 /$ jcm10050977

Academic Editor: Yasuhito Tanaka

Received: 20 December 2020

Accepted: 23 February 2021

Published: 2 March 2021

Publisher's Note: MDPI stays neutral with regard to jurisdictional claims in published maps and institutional affiliations.

Copyright: (c) 2021 by the authors. Licensee MDPI, Basel, Switzerland. This article is an open access article distributed under the terms and conditions of the Creative Commons Attribution (CC BY) license (https:/ / creativecommons.org/licenses/by/ $4.0 /)$.

\begin{abstract}
Despite breakthroughs in antiviral therapies, chronic viral hepatitis B and C are still the major causes of liver fibrosis and hepatocellular carcinoma (HCC). Importantly, even in patients with controlled infection or viral cure, the cancer risk cannot be fully eliminated, highlighting a persisting oncogenic pressure imposed by epigenetic imprinting and advanced liver disease. Reliable and minimally invasive biomarkers for early fibrosis and for residual HCC risk in HCV-cured patients are urgently needed. Chronic infection with HBV and/or HCV dysregulates oncogenic and profibrogenic signaling within the host, also displayed in the secretion of soluble factors to the blood. The study of virus-dysregulated signaling pathways may, therefore, contribute to the identification of reliable minimally invasive biomarkers for the detection of patients at early-stage liver disease potentially complementing existing noninvasive methods in clinics. With a focus on virus-induced signaling events, this review provides an overview of candidate blood biomarkers for liver disease and HCC risk associated with chronic viral hepatitis and epigenetic viral footprints.
\end{abstract}

Keywords: HBV; HCV; biomarkers; liver disease; HCC; cure; risk

\section{Introduction}

Chronic liver disease is a major health problem and globally associated with $>2$ million deaths per year [1]. The most important etiologies are chronic viral hepatitis, alcohol abuse and metabolic dysfunction-associated fatty liver disease (MAFLD) [2], sharing a similar pattern of liver disease progression from chronic inflammation, fibrosis to terminal complications, such as decompensated liver cirrhosis and liver cancer [3-6]. Globally, every fourth cancer-associated death is associated with liver cancer, most frequently hepatocellular carcinoma (HCC), with a fast-rising incidence [7]. HCC typically arises in the background of cirrhosis; however, in HCV patients, about $10 \%$ of cases can develop in a noncirrhotic liver [8].

Despite tremendous advances in antiviral therapies, chronic viral hepatitis B and C are still the major etiology for chronic liver disease. Worldwide, an estimated 180 million people live with hepatitis $B$ virus (HBV) and 75 million with hepatitis $C$ virus (HCV), and for most, testing and treatment remain beyond reach [9]. Both viruses share similar as well as distinct mechanisms contributing to liver disease and cancer. In Europe, it is estimated that $10-15 \%$ of HCCs are caused by HBV infection, while $70 \%$ are caused by $\mathrm{HCV}$ infection, HCV being the major risk factor for HCC development [10]. Both viruses contribute to liver fibrosis and HCC risk by multiple factors involving a dysregulation of host signal transduction through viral proteins, miRNAs, virus-induced growth factor and 
cytokine expression or antiviral responses that cumulate in a pro-fibrotic and pro-oncogenic environment in the liver [11-17]. Liver fibrosis is characterized by an excessive production of the extracellular matrix by hepatic stellate cells and myofibroblasts in response to the inflammation and oxidative stress induced by viral infection [18].

The most important measure to reduce HCC risk is to eliminate the underlying etiology. However, even though viral infection with HBV or HCV can be controlled or cured, the risk of developing HCC cannot be fully eradicated due to multiple reasons, especially in patients with already advanced liver disease. The mechanisms are not well understood, but evidence points towards epigenetic viral footprints that maintain dysregulated prooncogenic signal transduction. It is thus crucial to be able to identify patients with elevated HCC risk to stratify for a more frequent liver screening. Today, liver disease diagnosis and HCC risk assessment relies on a combination of imaging, blood markers and liver biopsies. While liver tissue allows a detailed transcriptomic HCC risk assessment linked to predictive transcriptomic signature $[19,20]$, liver biopsies are associated with a significant risk for the patients and, therefore, are not applicable for a tighter screening [21]. An impressive number of approaches and "liquid biomarker" candidates for liver disease are underway, studying extracellular vesicles, circulating tumor cells and cell-free nucleic acids (reviewed in detail [22]) to improve prognostic power, minimize the risk for the patients and provide additional tools for the screening of patients at risk. With a focus on virus-induced signaling events, this review provides an overview of the candidate blood biomarkers of fibrotic liver disease and HCC risk associated with chronic viral hepatitis.

\section{Viral Hepatitis B and C}

Although HBV and HCV are hepatotropic, causing similar liver disease, they are very different viruses. HBV is an hepatotropic DNA virus of the Hepadnaviridae family, which specifically infects hepatocytes via the recently discovered functional receptor sodium taurocholate co-transporting polypeptide (NTCP) [23] and epidermal growth factor signaling [24]. Following endocytosis, the nucleocapsid is released into the cytoplasm, and the partially double-stranded viral relaxed circular DNA (rcDNA) is repaired and converted to covalently closed circular DNA (cccDNA) in the nucleus (for a more detailed review, see [25]). cccDNA is a replicative intermediate of the HBV life cycle, and it is crucial for HBV persistence within the hepatocytes. It serves as a template for the transcription of HBV RNA species and consequently for the translation of HBV proteins, i.e., three surface proteins (L-HBsAg, M-HBsAg and S-HBsAg), core $(\mathrm{HBc})$, E antigen $(\mathrm{HBeAg})$, X protein $(\mathrm{HBx})$ and viral polymerase (Pol). Among them, $\mathrm{HBx}$ is believed to have key roles related to HBV replication and signaling pathways [26].

$\mathrm{HCV}$ is a single-stranded, positive-sense RNA virus of the Flaviviridae family that requires multiple host entry factors, including receptor tyrosine kinase signaling. After endocytosis, the RNA genome is translated into a viral polyprotein at the endoplasmic reticulum, leading to a massive reshaping of host membranes to a replication complex termed the membranous web. De novo virus assembles at lipid droplets, which are accumulated at the replication complex (for a more detailed review, see [27,28]). HCV does not integrate into the host genome nor possesses a latent viral phase. Thus, HCV requires a constant modulation of the host cell to evade the antiviral response and to maintain its viral cycle [29-31]. In contrast to HBV, which is considered to be a stealth virus that does not cause big changes in the host transcriptomics [32], HCV massively re-orchestrates signaling pathways. A multiomics analysis of HCV infection studying gene set enrichment analysis (GSEA) revealed that almost half of the 2000 studied gene sets from the molecular signature database (MSigDB) were dysregulated by HCV infection involving pro-oncogenic pathways regulating proliferation (EGF/MAPK), inflammation and stress (STAT3, NF- $\mathrm{B}$ ), hypoxia and angiogenesis (VEGFR) and fibrosis (TGF- $\beta$ ) $[16,17]$. Such massive remodulation of the signaling landscape holds the potential to derive novel minimally invasive biomarkers. 


\section{Antiviral Therapies}

The most important measure to treat liver disease and prevent HCC formation is the removal of the underlying etiology. The challenges to help patients with viral hepatitis are heterogenous: while an efficient preventive HBV vaccine is available, established chronic HBV infection can only be controlled but rarely eliminated due to a persistent chromosomelike viral DNA species and genome integrations [33]. A "functional cure" of HBV infection is defined by a sustained loss of hepatitis B surface antigen (HBsAg) in the blood, with or without seroconversion to anti-HBsAg. However, it is not always achieved in individuals with HBV. For this reason, the achievement of a sustained HBsAg seroclearance, even after suspension of the antiviral therapy, is nowadays considered the most realistic endpoint for the cure of individuals with chronic HBV. On the other hand, "virological cure", defined as the complete eradication of the virus, is too hard to reach, and it does not represent a reasonable therapeutic goal to date. This is due to the integration of HBV DNA into the host genome and the persistence of ccoDNA within the hepatocytes [34]. Importantly, a constant activation state of fibrotic signaling pathways is believed to persist even in patients with undetectable HBV serum viral loads after therapy [35-37].

For HCV, no vaccine is in reach, but the novel generation of antiviral therapies with direct acting antivirals (DAAs) can efficiently cure HCV infection [38]. A new generation of interferon-free HCV drug regimens (sofosbuvir/velpatasvir and glecaprevir/pibrentasvir) is pan-genotypic and, therefore, can be used to treat individuals without identifying their HCV genotype and subtype [38]. Efficiency is very high (90-98\% after 12 weeks; ASTRAL-3 trial) even in patients with difficult to treat genotype 3 and advanced liver disease [38]. However, the high price for $\mathrm{HCV}$ cure is still a barrier to guarantee treatment programs worldwide. Even when prices vary across countries, there is no adjustment of DAA prices with population income or viral infected population, making its accessibility more complicated for the poorest sectors of society [39]. HCV cure markedly decreases but cannot fully eliminate HCC risk, especially in patients with already advanced liver disease [40].

\section{Fibrosis and HCC Screening in the Clinics-State of the Art}

The majority of HCCs arise from liver cirrhosis, and thus the current HCC risk assessment is largely coupled to the staging of liver fibrosis. Despite the screening programs in cirrhotic patients, often the HCCs are diagnosed at an advanced stage. Less than 30-40\% of them are eligible for a curative treatment using surgical approaches or radiological ablation [41]. Currently, the trans-abdominal ultrasound surveillance of patients at risk is the standard technique to detect HCC. However, the sensitivity of this method is not good enough to detect small tumors. For this reason, other methods, e.g., computed tomography (CT) or magnetic resonance imaging (MRI), are added, increasing cost, complexity and time for early detection and diagnosis. Magnetic resonance elastography (MRE) can be thought of as quantitative, noninvasive palpation. The use of this technique has become widespread in the diagnosis and staging of liver fibrosis [42]. However, early detection of HCC is complicated because of the co-existence with a chronic liver disease. The performance of noninvasive methods is represented by the area under the receiver operator characteristic (AUROC) curve, which provides information regarding the sensitivity and specificity of the method. Based on this, several tests have been proposed, such as the fibrosis-4 index or fibrotest, which may help clinicians in determining prognosis and risk for future complications [43]. Another noninvasive method that helps in discriminating cirrhotic patients from noncirrhotic patients is the measurement of liver stiffness using transient elastography (TE), as the fibrotic tissue is much stiffer than healthy tissue. In patients with advanced fibrosis, the liver function and patient prognosis is classified with the Child-Pugh score summarizing biological and clinical features, i.e., bilirubin, albumin, prothrombin time, ascites and hepatic encephalopathy. Child-Pugh comprises 3 classes of severity: A, good liver functionality (median 2-year survival: 85\%); B, moderate liver 
functionality (median 2-year survival: 57\%); C, poor liver functionality (median 2-year survival: $35 \%$ ) [44].

Several patient-derived transcriptomic signatures that associate with HCC risk and which are specific for certain etiologies or reflect a hepatic state of struggle in the liver independently from the underlying etiology have been identified in recent years (for a more detailed review, see [45]). Although a translation into minimally invasive biomarkers is explored, these signatures largely depend on liver tissue from resections or liver biopsies, which are still the gold standard to diagnose liver disease and assess HCC risk. However, liver biopsies are costly, exhausting for the patients and associated with a significant risk, reasons why this procedure is not applicable for a tighter screening [21].

Current guidelines recommend the screening of HCC in at-risk patients using ultrasonography (US) of the liver every 6 months with or without serum alpha-fetoprotein (AFP) [46,47], the most commonly used biomarker for liver disease detection. Additional conventional serum biomarkers are lectin-binding AFP-3 (AFP-L3) and des-carboxyprothrombin (DCP), which are still evaluated [48-52]. A Japanese prospective study demonstrated that a combination of DCP with AFP level is useful to detect HCC development and recurrence in chronic liver disease patients [53]. This was recently consolidated by a retrospective study, which showed that combining DCP and AFP serum levels in NUC-treated HBV Caucasian cirrhotic individuals, represents a potential surveillance strategy for HCC [49]. Additional candidate biomarkers for HCC in the blood have been suggested, i.e., proprotein convertase subtilisin/kexin type 9 (PCSK9) [54,55], glypican 3 (GPC3), squamous cell carcinoma antigen (SCCA), cytokeratine-19, osteopontin (OPN), Golgi protein-73 (GP73), alpha-Lfucosidase (AFU) [56], heat shock $70 \mathrm{kD}$ protein (HSP-70) [57], annexin A2, midkine (MDK), aldo-keto reductase family 1 member B10 (AKR1B10) [58], and HCC-responsive miRNAs and cell-free DNA (for a more detailed review, see [59]). However, even if these candidate biomarkers are promising, to date, none of them have been adopted in the current clinical practice, and they need to be externally validated.

Additional scoring systems have been predictive for HCC risk in patients with chronic liver disease. The GALAD score $[60,61]$ is derived from the combination of different parameters and single biomarkers, such as gender, age, AFP-L3, AFP and DCP, and has been validated in several patient cohorts [62]. The ALBI score evaluates the liver function of patients with HCC of different stages based on albumin and bilirubin levels in the blood [63]. However, the complex mathematical calculation of the ALBI score has limited its use, and new scores based on it have been developed, e.g., EZ-ALBI [64] or the modified ALBI (mALBI) which is used in clinical practice [65]. The enhanced liver fibrosis (ELF) score assesses a range of liver disease in conjunction with liver biopsy [66]. It provides a single score combining in an algorithm the measurement of three indirect biomarkers: HA, PIIINP and TIMP-1. The algorithm detects accurately liver fibrosis in patients with chronic HCV [67]; however, it is limited in low disease prevalence [68].

\section{Signaling Pathways Associated with Candidate Serum Biomarkers}

Signal transduction is an essential process involved in almost every step of cellular homeostasis. Signaling is tightly controlled, transmitting signals between cellular compartments and regulating gene transcriptional responses. Thus, the chronic dysregulation of signaling pathways is involved in the majority of diseases, including cancer [69]. Viruses including HBV and HCV make use of host signaling to maintain their life cycles or to evade the host antiviral response. The resulting persistent dysregulation of host signaling pathways by chronic viral infection promotes viral pathogenesis and malignant transformation [70]. Therefore, the study of virus-dysregulated signaling pathways may contribute to identify efficient minimally invasive biomarkers for liver disease (Figure 1). 


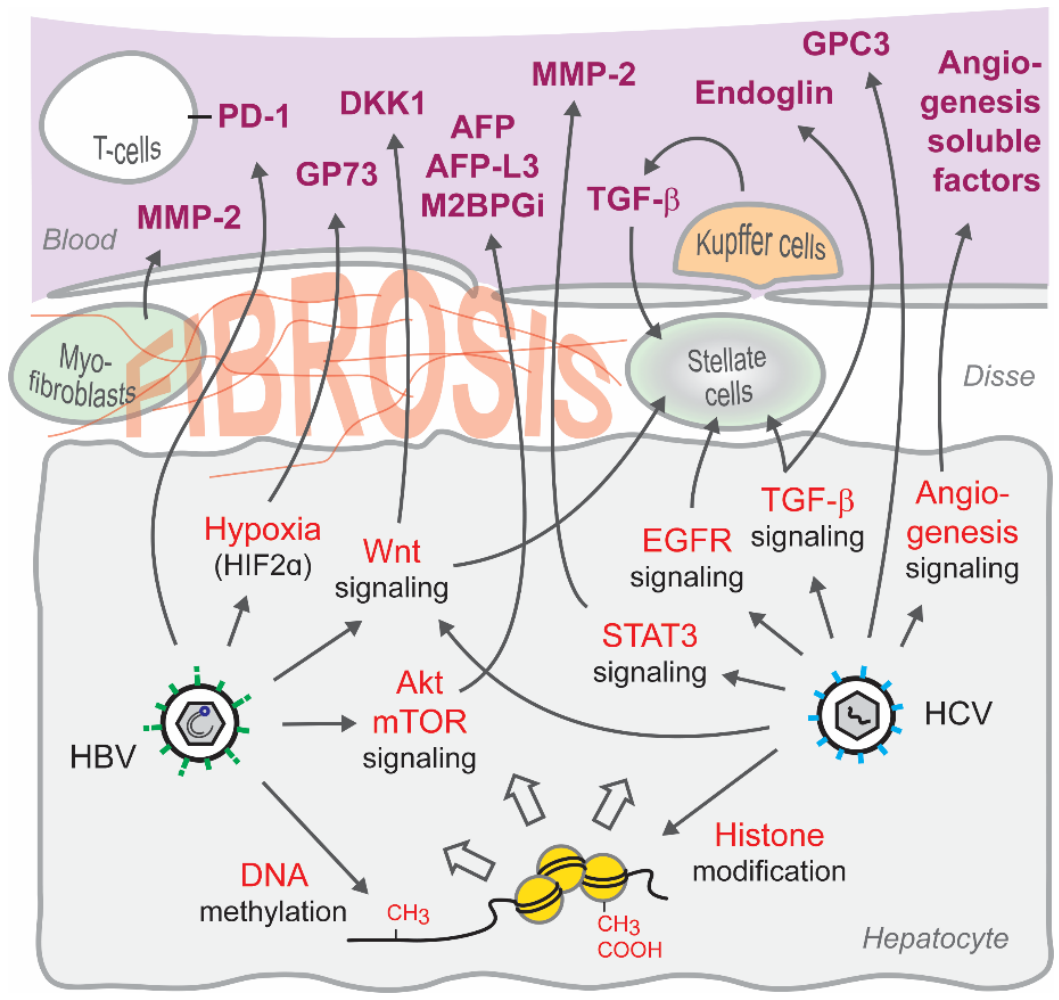

Figure 1. Dysregulation of signaling pathways by chronic viral hepatitis and epigenetic imprinting impact the secretion of circulating candidate biomarkers to the blood. Abbreviations: AFP, alphafetoprotein; AFP-L3, Lectin-Binding AFP-3; Akt, AKT Serine/Threonine Kinase; DKK1, Dickkopf WNT Signaling Pathway Inhibitor 1; Disse, Space of Disse; EGFR, Epidermal Growth Factor Receptor; GPC3, Glypican 3; GP73, Golgi Membrane Protein 1; HIF2 $\alpha$, Hypoxia-Inducible Factor 2 Alpha; M2BPGi, mac-2-binding protein glycan isomer; MMP-2, Matrix Metallopeptidase 2; mTOR, Mechanistic Target Of Rapamycin Kinase; PD-1, Programmed Cell Death 1; STAT3, Signal Transducer and Activator of Transcription 3; TGF- $\beta$, Transforming Growth Factor Beta; Wnt, Wnt Family Member.

Despite differences in terms of structure and life cycle, HBV and HCV are believed to share common pathways which influence hepatic fibrosis and promote hepatocarcinogenesis [71,72]. It became evident that HBV infection does not trigger the innate immune response and thus behaves as a stealth virus in the liver [73,74]. Nevertheless, chronic HBV infection impacts host signaling with potential relevance to markers of liver disease progression. The HCC biomarker AFP is also a regulator of growth signaling via PI3K/AKT signaling in hepatoma cells [75]. The viral protein HBx induces the expression of AFP, potentially driving the malignant transformation of hepatocytes in vivo via activation of the PI3K/AKT/mTOR pathway [76,77]. Moreover, members of the mTOR signaling pathway and eukaryotic translation initiation factors (eIFs) have recently been identified as potential biomarkers for HCC, and their expression patterns depend on different HCC aetiologias, such as HBV, HCV and non-virus-related HCC [78]. Another potential HBV-responsive risk marker is the protein Dickkopf WNT Signaling Pathway Inhibitor 1 (DKK1) involved in embryonic development as an inhibitor of Wnt signaling. DKK1 is a secreted protein whose mechanism of action is centered in binding and isolating the low-density lipoprotein receptor-related protein 6 (LRP6) co-receptor avoiding its role in activating the Wnt signaling pathway. DKK1 promotes HCC development by the modulation of the Wnt/ $\beta$-catenin signaling pathway [79] and interaction with TGF- $\beta$ signaling [80,81]. High serum levels of DKK1 may distinguish HCC associated with chronic HBV infection from HCC associated with nonviral liver cirrhosis. Moreover, DKK1 may allow early-stage HCC detection even in patients with AFP negative status [82]. DKK1 is also gaining interest as a potential biomarker for HCV-associated HCC. Although HCV core protein promotes the activation 
of the Wnt signaling protein and the suppression of Wnt pathway inhibitors [83,84], DKK1 abundance seems to be significantly decreased in the blood of patients with HCV [85]. However, DKK1 is spiking in patients with HCV who also have HCC [86].

GP73 has been suggested as a serum biomarker for liver cirrhosis in individuals with chronic HBV [87]. Moreover, GP73 seems to be a good predictor of liver inflammation and fibrosis in HBV patients with normal or slightly raised alanine aminotransferase (ALT) [88]. The biological function of GP73 is not completely understood but it is assumed to be involved in protein secretion and signaling. Moreover, its expression is linked to different pathological conditions [89]. HBV modulates various signaling pathways converging in GP73 modulation [90,91]. For example, it promotes GP73 expression by the activation of hypoxia-inducible factor- $2 \alpha$ (HIF-2 $\alpha$ ) signaling [91], which is a hallmark of chronic infection and HCC development. Moreover, GP73 influences the immune response to HBV infection, as an increased production of GP73 can be observed in HBV-stimulated leukocytes [90], in peripheral blood mononuclear cells isolated from healthy donors and in macrophages derived from human acute monocytic leukemia cells (THP-1). In the same study using hepatoma cell lines, the authors demonstrated that GP73 represses the expression of the p50 subunit of NF- $\mathrm{kB}$, promoting HBV replication and thus highlighting the role of GP73 as a potential antiviral modulator [90]. Immune dysregulation and T-cell exhaustion are among the major hallmarks of chronic HBV infection and the associated pathological development [92]. On this basis, the presence of HBV-specific T cells has been recently proposed as an immunological biomarker for safely monitoring therapy in chronic HBV patients [93] and programmed cell death protein (PD-1) expression as a potential marker for liver fibrosis in patients with chronic HBV [93].

Recently, mac-2-binding protein glycan isomer (M2BPGi) has been shown to enhance the aggressiveness of HCC via the activation of the mTOR signaling pathway [94], harboring potential as a minimally invasive biomarker. Glycoproteomic analysis has revealed that mac-2-binding protein (M2BP), an extracellular matrix protein that interacts with collagens, fibronectin and integrin [95], may undergo specific changes in its glycan structure correlating with fibrosis development $[95,96]$. M2BPGi has been suggested as a valid predictor of fibrosis and HCC in HBV patients [97-100]. Moreover, according to a prospective study conducted in China, M2BPGi serum level decreases in chronic HBV patients treated with nucleos(t)ide analogues (NAs), indicating its potential role in predicting HCC development in NA-treated populations [101]. In addition, M2BP-modified molecules have been studied as biomarkers of fibrosis in patients with chronic HCV infection [102]. Its cut-off values differ between etiologies, and M2BP levels decrease after viral cure [103]. Interestingly, M2BPGi has been introduced as a novel and noninvasive biomarker for the assessment of liver fibrosis in chronic HCV patients treated with DAAs [104].

Signaling pathways play a pivotal role during viral hepatitis and liver fibrosis. Epidermal growth factor receptor (EGFR) signaling is required by HBV and HCV for entry [24,105], where it orchestrates entry factor complex formation and endocytosis [24,106]. Importantly, HCV itself promotes EGFR signaling $[12,16,107]$ to maintain its life cycle and to attenuate the host antiviral response [106] with important consequences for liver disease progression. Indeed, EGFR signaling has been identified as a major driver of liver fibrosis and HCC in animal models and patients $[13,19]$. Additionally, TGF- $\beta$ signaling is induced by HCV infection in hepatocytes [16] and in activated Kupffer cells, which are resident liver macrophages activated during liver injury [108]. Like EGF and Wnt signaling, TGF- $\beta$ is a major regulator of cell proliferation, differentiation and apoptosis. It is essential for the induction of epithelial-mesenchymal transition (EMT) and the activation of stellate cells [108]. TGF- $\beta$ is a cytokine suppressing tumor activity at early stages by arresting cell growth and inducing apoptosis. However, at later tumor stages, it promotes the proliferation and survival of malignant cells (for a more detailed review, see [109]). HCV infection induces TGF- $\beta$ signaling indirectly via NF-kB and unfolded protein response (UPR) [110] and directly via the interaction of $\mathrm{HCV}$ core protein with SMAD3 [111]. HCV core protein 
increases intrahepatic and circulating levels of endoglin, which is a TGF- $\beta 1$ co-receptor associated with progressive hepatic fibrosis during chronic HCV infection [112].

Persistent oxidative stress is an important factor in virus-induced liver fibrosis. Especially $\mathrm{HCV}$ infection, and its massive reorganization of cellular membranes to the replication complex, is a major cause of UPR and oxidative stress [113]. HCV protein core, NS3 and NS5, block heme oxygenase-1 (HO-1) in hepatocytes accumulating oxygen radicals in the cell [114]. This activates NF-kB and STAT3 [113], which are key players in inflammation and cancer [115]. During HCV infection, STAT3 activity is further intensified by a suppression of negative regulators, i.e., the STAT3 phosphatase PTPRD via miR135a-5p [17] and SOCS3 by enhancing EGFR signaling [106]. Consequently, STAT3 signaling impairs peroxisomal function, leading to an accumulation of very-long-chain fatty acids and peroxides in the HCV-infected hepatocyte [16]. Moreover, HCV-induced STAT3 signaling also triggers the upregulation and secretion of the metalloprotease MMP-2 [116], which is involved in remodeling the extracellular matrix and has been previously suggested as a prognostic marker for liver fibrosis [117].

HCV infection induces hypoxia in infected cells and stabilizes HIFs [118], which is also a hallmark of HCC development linked to a stimulation of angiogenesis. In patients with $\mathrm{HCV}$-associated cirrhosis and HCC, several angiogenesis soluble factors were significantly upregulated in the blood plasma, including TIMP-1, TIMP-2, HGF, angiopoietin 1, angiopoietin 2, VEGFA, IP-10, PDGF, KGF and FGF. AUROC analysis highlighted especially the potential of angiopoietin 2, a growth factor that belongs to the angiopoietin/Tie signaling pathway [119-121]. Additionally, CCL20, a secreted chemokine detected in HCCs, promotes blood vessel formation during chronic HCV infection [122]. CCL20 and VEGF correlate in patients with cirrhosis and HCV-induced HCC, highlighting their potential as biomarkers for HCV-induced HCC [123-125]. Moreover, the serum level of TIMP-1 has been found to be significantly correlated with fibrosis development in chronic HBV patients [126]. Interestingly, a previous study demonstrated that TIMP-1 and hyaluronic acid (HA) are good predictors of advanced liver fibrosis in chronic hepatitis B and D patients [127] and bases for the earlier mentioned ELF score.

Glypican-3 (GPC3) is an heparan sulfate proteoglycan that regulates cell morphology via the Hippo/YAP pathway. In a normal liver, the HCV entry factor CD81 interacts with GPC3 and inhibits the Hippo/YAP pathway. HCV E2 protein mimics the role of CD81 stimulating Hippo/YAP by engaging GPC3. In a chronically inflamed liver, HCV is thus likely to promote hepatic neoplasia by the growth of early CD81-negative neoplastic hepatocytes, which are resistant to HCV infection [128]. Given its upregulation in the blood of patients with HCV-associated HCC, GPC3 had been suggested as a biomarker [129].

\section{Virus-Induced Epigenetic Changes as Biomarkers}

Epigenetic imprinting acts as a memory for environmental influences and disease [130]. This has long-term consequences to the cellular homeostasis and pathogenesis relevant not only for therapeutic strategies but which may also be instrumental to identify specific biomarkers. Epigenetic modifications comprise DNA methylation and posttranslational modification of histones, which directly regulates the accessibility of genes to the transcriptional machinery but also posttranscriptional regulation via noncoding RNAs [131]. The discovery of new epigenetic modulators is paving the way to the identification of new epigenetic biomarkers for the development of diagnostic and prognostic tools for hepatic fibrosis. It has been demonstrated that aberrant epigenetic signatures associated with fibrosis and HCC are released into the blood stream, providing blood-based biomarkers that could be used for advancing the diagnosis and prognosis of liver-associated diseases [132,133]. During chronic viral hepatitis, specific DNA methylation patterns in the genes of peripheral blood mononuclear cells (PBMCs) suggest a role in the progression of liver disease to HCC [134]. Methylation of cytosine-phospho-guanine (CpG) dinucleotides island in regulatory gene elements correlates with the silencing of the gene expression. Thus, a methylome analysis can identify dysregulated disease-relevant signaling pathways. This 
strategy highlighted a role of dysregulated IL-15, IL-8, as well as nitric oxide signaling in PBMCs from HBV patients and cirrhotic livers causing reprogramming of the immune and inflammatory responses [135]. HBV causes a virus-specific DNA methylation pattern in the hepatocyte DNA [136], which, however, in a study from 2015 on primary human hepatocytes had only limited overlap with the transcriptional pattern [137]. Circulating methylated DNA fragments are explored as a noninvasive diagnostic tool for early-stage liver cancer prevention [138-140]. Interestingly, this also includes methylated fragments of the SOCS3 gene [139], which is a negative regulator of the IL-6/STAT3 signaling pathway.

Epigenetic regulation of gene expression by $\mathrm{HCV}$ has been observed at the histone level. Such epigenetic footprints have been identified in cell lines and patients with chronic HCV infection and NASH [141-143], suggesting a lasting dysregulation of signaling pathways even after the underlying cause has eased. Indeed, comparative ChIP-seq and RNA-seq analysis of DAA-cured HCV patients identified epigenetic histone modifications. These were associated with the dysregulated pro-oncogenic transcriptional pattern, suggesting a persistently dysregulated signal transduction after viral cure [141]. Comparative analysis with HCV-infected and DAA-cured human liver chimeric mice highlighted an $\mathrm{HCV}$-specific viral footprint, since these mice do not develop liver fibrosis, which also involves the STAT3 phosphatase PTPRD [141]. Moreover, a liver fibrosis-specific footprint of cancer-risk genes has been identified in $\mathrm{HCV}$ - and NASH-associated fibrotic patients livers [142]. However, a translation of these footprint signatures into blood born biomarkers is pending.

HCV infection and liver disease largely impact miRNA expression [11], which influences signaling pathway activity and liver disease progression [17]. Circulating miRNAs harbor the potential of being developed into minimally invasive biomarkers [144,145]. miRNAs are enriched and well protected in extracellular vesicles (EVs) in the blood. Exosomal miRNAs have been evaluated in clinics, such as miR-122 and miR-21, for the early detection and prediction of HCC [146], and let-7s for the detection of liver fibrosis in patients with chronic hepatitis C infection $[145,147]$.

\section{Discussion and Perspectives}

Although HBV and HCV cause both liver disease progression and HCC, the clinical challenges differ substantially. HBV infection can only be controlled but not eradicated because of a persisting chromosome-like cccDNA and genome integration [36]. HCV infection is now curable; however, chronic infection is leaving an epigenetic footprint that manifests the dysregulation of the pro-oncogenic signal beyond viral eradication. In both cases, patients remain at considerable risk to develop HCC over the years, which highlights the importance of reliable and minimally invasive biomarkers to stratify these risk patients for tighter HCC screening. A combination of circulating signaling components, secondary markers (e.g., gut microbiome $[148,149])$, with noninvasive imaging biomarkers will hold the biggest potential. However, it is important to remark that although some of these signaling-linked candidate biomarkers show promising results, almost all of them are still in development, and only AFP has reached phase V (Table 1). Moreover, it is generally difficult to draw a line between biomarkers derived from the pro-fibrotic signaling events and carcinogenesis markers during end stage liver disease. While the dysregulated signaling and epigenetics in diseased livers partially overlap between etiologies, e.g., $\mathrm{HCV}$ and MAFLD [13,16,141,142,150], hepatocarcinogenesis is a highly heterogenous event even within a specific etiology $[151,152]$. This, we need novel concepts, which differentiate those markers that "simply" predict increased fibrogenesis from those that are definitively associated with risk of carcinogenesis. 
Table 1. Promising minimally invasive biomarker candidates with links to virus-induced signaling $(\mathrm{HBV}, \mathrm{HCV})$ and predictive of liver fibrosis and HCC. Biomarker research is categorized into phases I-V [153]: phase V (evaluates the effect of the biomarker screening in the burden of the disease in the population), phase IV (prospective evaluation of the biomarker to assess its clinical performance), phase III (testing in patients before their diagnosis to determine the performance of the biomarker in detecting pre-clinical disease), phase II (testing in patients at high risk to determine the performance of the biomarker in distinguishing between patients with and without the disease), phase I (discovery of new biomarkers by investigating gene expression and protein levels in pathological tissue and patient samples).

\begin{tabular}{ccccc}
\hline Biomarker & Specificity & Viral Etiology & $\begin{array}{c}\text { Development } \\
\text { Status }\end{array}$ & Reference \\
\hline AFP & HCC & HBV, HCV & Phase V & {$[41,46,47,51,52,77,101]$} \\
\hline DCP & HCC & HBV, HCV & Phase IV & {$[48-53]$} \\
\hline M2BPGi & HCC & HBV, HCV & Phase IV & {$[95-104]$} \\
\hline MDK & HCC & HCV & Phase III & {$[81,154]$} \\
\hline OPN & HCC, fibrosis & HBV, HCV & Phase III & {$[155-157]$} \\
\hline Annexin A2 & HCC, fibrosis & HBV, HCV & Phase II & {$[158,159]$} \\
\hline DKK1 & HCC & HBV, HCV & Phase II & {$[81,82,85,86]$} \\
\hline GPC3 & HCC & HCV & Phase II & {$[128,129]$} \\
\hline HSP-70 & HCC & HBV, HCV & Phase II & {$[57]$} \\
\hline PCSK9 & HCC & HCV & Phase II & {$[54,55]$} \\
\hline SCCA & HCC, fibrosis & HCV & Phase II & {$[160,161]$} \\
\hline TIMP-1 & Fibrosis & HBV, HCV & Phase II & {$[119,126]$} \\
\hline Angiopoietin-2 & HCC, fibrosis & HCV & Phase I & {$[119-121]$} \\
\hline CCL20 & HCC & HCV & Phase I & {$[122,123]$} \\
\hline Endoglin & Fibrosis & HCV & Phase I & {$[112]$} \\
\hline VEGF & HCC, fibrosis & HCV & Phase I & {$[119,123-125]$} \\
\hline
\end{tabular}

While HCV infection was rendered a curable disease due to efficient direct antiviral therapies, an important unmet medical need is to identify the fraction of patients with elevated HCC risk. In future, etiology-specific epigenetic markers, including histone modifications and miRNAs, will provide new perspectives for translation into correlating secreted biomarkers, which may be used for personalized approaches targeting specific groups of patients, e.g., biomarkers for HCC risk in $\mathrm{HCV}$-cured patients.

Author Contributions: A.V., V.G.-M., S.T., T.F.B., J.L. conceptualized and wrote the manuscript. All authors have read and agreed to the published version of the manuscript.

Funding: This work was funded by the European Union (EU H2020 HEPCAR 667273 to J.L. and T.F.B.), the French Cancer Agency (TheraHCC2.0 IHU201901299), the Agence Nationale de Recherche sur le Sida et les hépatites virales (ANRS ECTZ103701 and ECTZ131760 to J.L., ANRS ECTZ ECTZ104017 and ECTZ75178 to T.F.B.), the Fondation de l'Universite de Strasbourg (HEPKIN) (TBA-DON-0002) and the Inserm Plan Cancer 2019-2023. This work has benefitted from support from the Initiative of excellence IDEX-Unistra (ANR-10-IDEX-0002-02) and has been published under the framework of the LABEX ANR-10-LAB-28 (HEPSYS). Inserm Plan Cancer, IDEX and LABEX are initiatives from the French program "Investments for the future".

Conflicts of Interest: The authors declare no conflict of interest.

\section{References}

1. Asrani, S.K.; Devarbhavi, H.; Eaton, J.; Kamath, P.S. Burden of Liver Diseases in the World. J. Hepatol. 2019, 70, 151-171. [CrossRef] [PubMed]

2. Tilg, H.; Effenberger, M. From NAFLD to MAFLD: When Pathophysiology Succeeds. Nat. Rev. Gastroenterol. Hepatol. 2020, 17, 387-388. [CrossRef] 
3. Baumert, T.F.; Berg, T.; Lim, J.K.; Nelson, D.R. Status of Direct-Acting Antiviral Therapy for Hepatitis C Virus Infection and Remaining Challenges. Gastroenterology 2019, 156, 431-445. [CrossRef] [PubMed]

4. Chung, R.T.; Baumert, T.F. Curing Chronic Hepatitis C-The Arc of a Medical Triumph. N. Engl. J. Med. 2014, 370, 1576-1578. [CrossRef] [PubMed]

5. Friedman, S.L.; Neuschwander-Tetri, B.A.; Rinella, M.; Sanyal, A.J. Mechanisms of NAFLD Development and Therapeutic Strategies. Nat. Med. 2018, 24, 908-922. [CrossRef]

6. Villanueva, A. Hepatocellular Carcinoma. N. Engl. J. Med. 2019, 380, 1450-1462. [CrossRef]

7. Tang, A.; Hallouch, O.; Chernyak, V.; Kamaya, A.; Sirlin, C.B. Epidemiology of Hepatocellular Carcinoma: Target Population for Surveillance and Diagnosis. Abdom. Radiol. 2018, 43, 13-25. [CrossRef]

8. Desai, A.; Sandhu, S.; Lai, J.-P.; Sandhu, D.S. Hepatocellular Carcinoma in Non-cirrhotic Liver: A Comprehensive Review. World J. Hepatol. 2019, 11, 1-18. [CrossRef] [PubMed]

9. WHO. Global Hepatitis Report; WHO: Geneva, Switzerland, 2017.

10. Bray, F.; Ferlay, J.; Soerjomataram, I.; Siegel, R.L.; Torre, L.A.; Jemal, A. Global Cancer Statistics 2018: GLOBOCAN Estimates of Incidence and Mortality Worldwide for 36 Cancers in 185 Countries. CA Cancer J. Clin. 2018, 68, 394-424. [CrossRef]

11. Bandiera, S.; Pernot, S.; El Saghire, H.; Durand, S.C.; Thumann, C.; Crouchet, E.; Ye, T.; Fofana, I.; Oudot, M.A.; Barths, J.; et al. Hepatitis C Virus-Induced Upregulation of MicroRNA miR-146a-5p in Hepatocytes Promotes Viral Infection and Deregulates Metabolic Pathways Associated with Liver Disease Pathogenesis. J. Virol. 2016, 90, 6387-6400. [CrossRef]

12. Diao, J.; Pantua, H.; Ngu, H.; Komuves, L.; Diehl, L.; Schaefer, G.; Kapadia, S.B. Hepatitis C Virus Induces Epidermal Growth Factor Receptor Activation via CD81 Binding for Viral Internalization and Entry. J. Virol. 2012, 86, 10935-10949. [CrossRef]

13. Fuchs, B.C.; Hoshida, Y.; Fujii, T.; Wei, L.; Yamada, S.; Lauwers, G.Y.; McGinn, C.M.; Deperalta, D.K.; Chen, X.; Kuroda, T.; et al. Epidermal Growth Factor Receptor Inhibition Attenuates Liver Fibrosis and Development of Hepatocellular Carcinoma. Hepatology 2014, 59, 1577-1590. [CrossRef]

14. Igloi, Z.; Kazlauskas, A.; Saksela, K.; Macdonald, A.; Mankouri, J.; Harris, M. Hepatitis C virus NS5A Protein Blocks Epidermal Growth Factor Receptor Degradation via a Proline Motif-Dependent Interaction. J. Gen. Virol. 2015, 96, 2133-2144. [CrossRef]

15. Lou, W.; Liu, J.; Ding, B.; Chen, D.; Xu, L.; Ding, J.; Jiang, D.; Zhou, L.; Zheng, S.; Fan, W. Identification of Potential miRNA-mRNA Regulatory Network Contributing to Pathogenesis of HBV-Related HCC. J. Transl. Med. 2019, 17, 1-14. [CrossRef]

16. Lupberger, J.; Croonenborghs, T.; Suarez, A.A.R.; Van Renne, N.; Jühling, F.; Oudot, M.A.; Virzì, A.; Bandiera, S.; Jamey, C.; Meszaros, G.; et al. Combined Analysis of Metabolomes, Proteomes, and Transcriptomes of Hepatitis C Virus-Infected Cells and Liver to Identify Pathways Associated with Disease Development. Gastroenterology 2019, 157, 537-551.e9. [CrossRef]

17. Van Renne, N.; Suarez, A.A.R.; Duong, F.H.T.; Gondeau, C.; Calabrese, D.; Fontaine, N.; Ababsa, A.; Bandiera, S.; Croonenborghs, T.; Pochet, N.; et al. miR-135a-5p-Mediated Downregulation of Protein Tyrosine Phosphatase Receptor Delta Is a Candidate Driver of HCV-Associated Hepatocarcinogenesis. Gut 2017, 67, 953-962. [CrossRef]

18. Yavuz, B.G.; Pestana, R.C.; AbuGabal, Y.I.; Krishnan, S.; Chen, J.; Hassan, M.M.; Wolff, R.A.; Rashid, A.; Amin, H.M.; Kaseb, A.O Origin and Role of Hepatic Myofibroblasts in Hepatocellular Carcinoma. Oncotarget 2020, 11, 1186-1201. [CrossRef] [PubMed]

19. Hoshida, Y.; Villanueva, A.; Kobayashi, M.; Peix, J.; Chiang, D.Y.; Camargo, A.; Gupta, S.; Moore, J.; Wrobel, M.J.; Lerner, J.; et al. Gene Expression in Fixed Tissues and Outcome in Hepatocellular Carcinoma. N. Engl. J. Med. 2008, 359, 1995-2004. [CrossRef]

20. Hoshida, Y.; Villanueva, A.; SanGiovanni, A.; Sole, M.; Hur, C.; Andersson, K.L.; Chung, R.T.; Gould, J.; Kojima, K.; Gupta, S.; et al. Prognostic Gene Expression Signature for Patients with Hepatitis C-Related Early-Stage Cirrhosis. Gastroenterology 2013, 144, 1024-1030. [CrossRef] [PubMed]

21. Castera, L.; Friedrich-Rust, M.; Loomba, R. Noninvasive Assessment of Liver Disease in Patients with Nonalcoholic Fatty Liver Disease. Gastroenterology 2019, 156, 1264-1281.e4. [CrossRef] [PubMed]

22. Mann, J.; Reeves, H.L.; Feldstein, E.A. Liquid Biopsy for Liver Diseases. Gut 2018, 67, 2204-2212. [CrossRef] [PubMed]

23. Yan, H.; Zhong, G.; Xu, G.; He, W.; Jing, Z.; Gao, Z.; Huang, Y.; Qi, Y.; Peng, B.; Wang, H.; et al. Sodium Taurocholate Cotransporting Polypeptide Is a Functional Receptor for Human Hepatitis B and D Virus. eLife 2012, 1, e00049. [CrossRef] [PubMed]

24. Iwamoto, M.; Saso, W.; Sugiyama, R.; Ishii, K.; Ohki, M.; Nagamori, S.; Suzuki, R.; Aizaki, H.; Ryo, A.; Yun, J.-H.; et al. Epidermal Growth Factor Receptor Is a Host-Entry Cofactor Triggering Hepatitis B Virus Internalization. Proc. Natl. Acad. Sci. USA 2019, 116, 8487-8492. [CrossRef] [PubMed]

25. Tsukuda, S.; Watashi, K. Hepatitis B Virus Biology and Life Cycle. Antivir. Res. 2020, 182, 104925. [CrossRef] [PubMed]

26. Lucifora, J.; Arzberger, S.; Durantel, D.; Belloni, L.; Strubin, M.; Levrero, M.; Zoulim, F.; Hantz, O.; Protzer, U. Hepatitis B Virus X Protein Is Essential to Initiate and Maintain Virus Replication after Infection. J. Hepatol. 2011, 55, 996-1003. [CrossRef]

27. Colpitts, C.C.; Tsai, P.-L.; Zeisel, M.B. Hepatitis C Virus Entry: An Intriguingly Complex and Highly Regulated Process. Int. J. Mol. Sci. 2020, 21, 2091. [CrossRef] [PubMed]

28. Tabata, K.; Neufeldt, C.J.; Bartenschlager, R. Hepatitis C Virus Replication. Cold Spring Harb. Perspect. Med. 2019, 10, a037093. [CrossRef] [PubMed]

29. Cheng, Y.; Sun, F.; Wang, L.; Gao, M.; Xie, Y.; Sun, Y.; Liu, H.; Yuan, Y.; Yi, W.; Huang, Z.; et al. Virus-Induced p38 MAPK Activation Facilitates Viral Infection. Theranostics 2020, 10, 12223-12240. [CrossRef]

30. Negash, A.A.; Olson, R.M.; Griffin, S.; Gale, M. Modulation of Calcium Signaling Pathway by Hepatitis C Virus Core Protein Stimulates NLRP3 Inflammasome Activation. PLoS Pathog. 2019, 15, e1007593. [CrossRef] [PubMed] 
31. Virzì, A.; Suarez, A.A.R.; Baumert, T.F.; Lupberger, J. Oncogenic Signaling Induced by HCV Infection. Viruses 2018, $10,538$. [CrossRef] [PubMed]

32. König, A.; Yang, J.; Jo, E.; Park, K.H.P.; Kim, H.; Than, T.T.; Song, X.; Qi, X.; Dai, X.; Park, S.; et al. Efficient Long-Term Amplification of Hepatitis B Virus Isolates after Infection of Slow Proliferating HepG2-NTCP Cells. J. Hepatol. 2019, 71, 289-300. [CrossRef]

33. Fanning, G.C.; Zoulim, F.; Hou, J.; Bertoletti, A. Therapeutic Strategies for Hepatitis B Virus Infection: Towards a Cure. Nat. Rev. Drug Discov. 2019, 18, 827-844. [CrossRef] [PubMed]

34. Lok, A.S.; Zoulim, F.; Dusheiko, G.; Ghany, M.G. Hepatitis B Cure: From Discovery to Regulatory Approval. Hepatology 2017, 66, 1296-1313. [CrossRef]

35. Mu, D.; Yuan, F.-C.; Chen, Y.; Jiang, X.-Y.; Yan, L.; Jiang, L.-Y.; Gong, J.-P.; Zhang, D.-Z.; Ren, H.; Liao, Y. Baseline Value of Intrahepatic HBV DNA Over cccDNA Predicts Patient's Response to Interferon Therapy. Sci. Rep. 2017, 7, 5937. [CrossRef] [PubMed]

36. Nassal, M. HBV cccDNA: Viral Persistence Reservoir and Key Obstacle for a Cure of Chronic Hepatitis B. Gut 2015, 64, 1972-1984. [CrossRef] [PubMed]

37. Zhang, X.; Lu, W.; Zheng, Y.; Wang, W.; Bai, L.; Chen, L.; Feng, Y.; Zhang, Z.; Yuan, Z. In Situ Analysis of Intrahepatic Virological Events in Chronic Hepatitis B Virus Infection. J. Clin. Investig. 2016, 126, 1079-1092. [CrossRef] [PubMed]

38. European Association for the Study of the Liver. Electronic Address Eee, Clinical Practice Guideline Panel C, Panel m, Representative EGB. EASL Clinical Practice Guidelines: Drug-Induced Liver Injury. J. Hepatol. 2020, 73, 1170-1218. [CrossRef]

39. Lu, C.Y.; Ross-Degnan, D.; Zhang, F.; LeCates, R.; Lupton, C.; Sherman, M.; Wagner, A. Cost Burden of Hepatitis C Virus Treatment in Commercially Insured Patients. Am J Manag Care 2019, 25, e379-e387.

40. Baumert, T.F.; Jühling, F.; Ono, A.; Hoshida, Y. Hepatitis C-Related Hepatocellular Carcinoma in the Era of New Generation Antivirals. BMC Med. 2017, 15, 1-10. [CrossRef] [PubMed]

41. Chan, S.L.; Mo, F.; Johnson, P.J.; Siu, D.Y.W.; Chan, M.H.M.; Lau, W.Y.; Lai, P.B.S.; Lam, C.W.K.; Yeo, W.; Yu, S.C.H. Performance of Serum $\alpha$-Fetoprotein Levels in the Diagnosis of Hepatocellular Carcinoma in Patients with a Hepatic Mass. HPB 2014, 16, 366-372. [CrossRef]

42. Manduca, A.; Bayly, P.J.; Ehman, R.L.; Kolipaka, A.; Royston, T.J.; Sack, I.; Sinkus, R.; Van Beers, B.E. MR Elastography: Principles, Guidelines, and Terminology. Magn. Reson. Med. 2021, 85, 2377-2390. [CrossRef]

43. European Association for the Study of the Liver; Asociación Latinoamericana para el Estudio del Hígado. EASL-ALEH Clinical Practice Guidelines: Non-Invasive Tests for Evaluation of Liver Disease Severity and Prognosis. J. Hepatol. 2015, 63, 237-264. [CrossRef]

44. Tsoris, A.; Marlar, C.A. Use of the Child Pugh Score in Liver Disease; StatPearls: Treasure Island, FL, USA, 2020.

45. Kubota, N.; Fujiwara, N.; Hoshida, Y. Clinical and Molecular Prediction of Hepatocellular Carcinoma Risk. J. Clin. Med. 2020, 9 , 3843. [CrossRef]

46. European Association for the Study of the Liver. Electronic Address Eee, European Association for the Study of the L. EASL Clinical Practice Guidelines: Management of Hepatocellular Carcinoma. J. Hepatol. 2018, 69, 182-236. [CrossRef]

47. Heimbach, J.K.; Kulik, L.M.; Finn, R.S.; Sirlin, C.B.; Abecassis, M.M.; Roberts, L.R.; Zhu, A.X.; Murad, M.H.; Marrero, J.A. AASLD Guidelines for the Treatment of Hepatocellular Carcinoma. Hepatology 2018, 67, 358-380. [CrossRef] [PubMed]

48. Ertle, J.M.; Heider, D.; Wichert, M.; Keller, B.; Kueper, R.; Hilgard, P.; Gerken, G.; Schlaak, J.F. A Combination of A-Fetoprotein and Des- $\gamma$-Carboxy Prothrombin Is Superior in Detection of Hepatocellular Carcinoma. Digestion 2013, 87, 121-131. [CrossRef]

49. Loglio, A.; Iavarone, M.; Facchetti, F.; Di Paolo, D.; Perbellini, R.; Lunghi, G.; Ceriotti, F.; Galli, C.; Sandri, M.T.; Viganò, M.; et al. The Combination of PIVKA-II and AFP Improves the Detection Accuracy for HCC in HBV Caucasian Cirrhotics on Long-Term Oral Therapy. Liver Int. 2020, 40, 1987-1996. [CrossRef] [PubMed]

50. Ji, J.; Wang, H.; Li, Y.; Zheng, L.; Yin, Y.; Zou, Z.; Zhou, F.; Zhou, W.; Shen, F.; Gao, C. Diagnostic Evaluation of Des-GammaCarboxy Prothrombin versus $\alpha$-Fetoprotein for Hepatitis B Virus-Related Hepatocellular Carcinoma in China: A Large-Scale, Multicentre Study. PLoS ONE 2016, 11, e0153227. [CrossRef]

51. Song, T.; Wang, L.; Su, B.; Zeng, W.; Jiang, T.; Zhang, T.; Sun, G.; Wu, H. Diagnostic Value of Alpha-Fetoprotein, Lens Culinaris Agglutinin-Reactive Alpha-Fetoprotein, and Des-Gamma-Carboxyprothrombin in Hepatitis B Virus-Related Hepatocellular Carcinoma. J. Int. Med. Res. 2020, 48, 0300060519889270. [CrossRef]

52. Wang, X.; Zhang, Y.; Yang, N.; He, H.; Tao, X.; Kou, C.; Jiang, J. Evaluation of the Combined Application of AFP, AFP-L3\%, and DCP for Hepatocellular Carcinoma Diagnosis: A Meta-Analysis. BioMed Res. Int. 2020, 2020, 1-10. [CrossRef]

53. Ikoma, J.; Kaito, M.; Ishihara, T.; Nakagawa, N.; Kamei, A.; Fujita, N.; Iwasa, M.; Tamaki, S.; Watanabe, S.; Adachi, Y. Early Diagnosis of Hepatocellular Carcinoma Using a Sensitive Assay for Serum Des-Gamma-Carboxy Prothrombin: A Prospective Study. Hepatogastroenterology 2002, 49, 235-238.

54. Fasolato, S.; Pigozzo, S.; Pontisso, P.; Angeli, P.; Ruscica, M.; Savarino, E.; De Martin, S.; Lupo, M.G.; Ferri, N. PCSK9 Levels Are Raised in Chronic HCV Patients with Hepatocellular Carcinoma. J. Clin. Med. 2020, 9, 3134. [CrossRef]

55. Wiciński, M.; Żak, J.; Malinowski, B.; Popek, G.; Grześk, G. PCSK9 Signaling Pathways and Their Potential Importance in Clinical Practice. EPMA J. 2017, 8, 391-402. [CrossRef] [PubMed]

56. Zhang, S.-Y.; Lin, B.-D.; Li, B.-R. Evaluation of the Diagnostic Value of Alpha-L-Fucosidase, Alpha-Fetoprotein and Thymidine Kinase 1 with Roc and Logistic Regression for Hepatocellular Carcinoma. FEBS Open Bio 2015, 5, 240-244. [CrossRef] 
57. Moudi, B.; Heidari, Z.; Mahmoudzadeh-Sagheb, H.; Alavian, S.-M.; Lankarani, K.B.; Farrokh, P.; Nyengaard, J.R. Concomitant Use of Heat-Shock Protein 70, Glutamine Synthetase and Glypican-3 Is Useful in Diagnosis of HBV-Related Hepatocellular Carcinoma with Higher Specificity and Sensitivity. Eur. J. Histochem. 2018, 62, 2859. [CrossRef] [PubMed]

58. Murata, A.; Genda, T.; Ichida, T.; Amano, N.; Sato, S.; Tsuzura, H.; Sato, S.; Narita, Y.; Kanemitsu, Y.; Shimada, Y.; et al. Pretreatment AKR1B10 Expression Predicts the Risk of Hepatocellular Carcinoma Development after Hepatitis C Virus Eradication. World J. Gastroenterol. 2016, 22, 7569-7578. [CrossRef] [PubMed]

59. Lou, J.; Zhang, L.; Lv, S.; Zhang, C.; Jiang, S. Biomarkers for Hepatocellular Carcinoma. Biomark. Cancer 2017, 9, 1-9. [CrossRef] [PubMed]

60. Best, J.; Bechmann, L.P.; Sowa, J.-P.; Sydor, S.; Dechêne, A.; Pflanz, K.; Bedreli, S.; Schotten, C.; Geier, A.; Berg, T.; et al. GALAD Score Detects Early Hepatocellular Carcinoma in an International Cohort of Patients with Nonalcoholic Steatohepatitis. Clin. Gastroenterol. Hepatol. 2020, 18, 728-735.e4. [CrossRef]

61. Johnson, P.J.; Pirrie, S.J.; Cox, T.F.; Berhane, S.; Teng, M.; Palmer, D.; Morse, J.; Hull, D.; Patman, G.; Kagebayashi, C.; et al. The Detection of Hepatocellular Carcinoma Using a Prospectively Developed and Validated Model Based on Serological Biomarkers. Cancer Epidemiol. Biomark. Prev. 2014, 23, 144-153. [CrossRef]

62. Yang, J.D.; Addissie, B.D.; Mara, K.C.; Harmsen, W.S.; Dai, J.; Zhang, N.; Wongjarupong, N.; Ali, H.M.; Ali, H.A.; Hassan, F.A.; et al. GALAD Score for Hepatocellular Carcinoma Detection in Comparison with Liver Ultrasound and Proposal of GALADUS Score. Cancer Epidemiol. Biomark. Prev. 2019, 28, 531-538. [CrossRef]

63. Johnson, P.J.; Berhane, S.; Kagebayashi, C.; Satomura, S.; Teng, M.; Reeves, H.L.; O’Beirne, J.; Fox, R.; Skowronska, A.; Palmer, D.; et al. Assessment of Liver Function in Patients With Hepatocellular Carcinoma: A New Evidence-Based Approach-The ALBI Grade. J. Clin. Oncol. 2015, 33, 550-558. [CrossRef] [PubMed]

64. Kariyama, K.; Nouso, K.; Hiraoka, A.; Wakuta, A.; Oonishi, A.; Kuzuya, T.; Toyoda, H.; Tada, T.; Tsuji, K.; Itobayashi, E.; et al. EZ-ALBI Score for Predicting Hepatocellular Carcinoma Prognosis. Liver Cancer 2020, 9, 734-743. [CrossRef]

65. Dieter, P.; Altin, J.G.; Decker, K.; Bygrave, F.L. Possible Involvement of Eicosanoids in the Zymosan and Arachidonic-AcidInduced Oxygen Uptake, Glycogenolysis and $\mathrm{Ca}^{2+}$ Mobilization in the Perfused Rat Liver. JBIC J. Biol. Inorg. Chem. 1987, 165, 455-460. [CrossRef] [PubMed]

66. Rosenberg, W.; Voelker, M.; Thiel, R.; Becka, M.; Burtb, A.; Schuppan, D.; Hubscher, S.; Roskams, T.; Pinzani, M.; Arthur, M.J. Serum Markers Detect the Presence of Liver Fibrosis: A Cohort Study. Gastroenterology 2004, 127, 1704-1713. [CrossRef] [PubMed]

67. Parkes, J.; Guha, I.N.; Roderick, P.; Harris, S.; Cross, R.; Manos, M.M.; Irving, W.; Zaitoun, A.; Wheatley, M.; Ryder, S.; et al. Enhanced Liver Fibrosis (ELF) Test Accurately Identifies Liver Fibrosis in Patients with Chronic Hepatitis C. J. Viral Hepat. 2010, 18, 23-31. [CrossRef]

68. Vali, Y.; Lee, J.; Boursier, J.; Spijker, R.; Löffler, J.; Verheij, J.; Brosnan, M.J.; Böcskei, Z.; Anstee, Q.M.; Bossuyt, P.M.; et al. Enhanced Liver Fibrosis Test for the Non-invasive Diagnosis of Fibrosis in Patients With NAFLD: A Systematic Review and Meta-Analysis. J. Hepatol. 2020, 73, 252-262. [CrossRef]

69. Lemmon, M.A.; Schlessinger, J. Cell Signaling by Receptor Tyrosine Kinases. Cell 2010, 141, 1117-1134. [CrossRef]

70. Krump, N.A.; You, J. Molecular Mechanisms of Viral Oncogenesis in Humans. Nat. Rev. Genet. 2018, 16, 684-698. [CrossRef]

71. Cong, M.; Iwaisako, K.; Jiang, C.; Kisseleva, T. Cell Signals Influencing Hepatic Fibrosis. Int. J. Hepatol. 2012, 2012, 1-18. [CrossRef]

72. Szabó, E.; Páska, C.; Novák, P.K.; Schaff, Z.; Kiss, A. Similarities and Differences in Hepatitis B and C Virus Induced Hepatocarcinogenesis. Pathol. Oncol. Res. 2004, 10, 5-11. [CrossRef]

73. Faure-Dupuy, S.; Lucifora, J.; Durantel, D. Interplay between the Hepatitis B Virus and Innate Immunity: From an Understanding to the Development of Therapeutic Concepts. Viruses 2017, 9, 95. [CrossRef] [PubMed]

74. Suslov, A.; Boldanova, T.; Wang, X.; Wieland, S.; Heim, M.H. Hepatitis B Virus Does Not Interfere with Innate Immune Responses in the Human Liver. Gastroenterology 2018, 154, 1778-1790. [CrossRef] [PubMed]

75. Li, M.; Li, H.; Li, C.; Wang, S.; Jiang, W.; Liu, Z.; Zhou, S.; Liu, X.; McNutt, M.A.; Li, G. Alpha-Fetoprotein: A New Member of Intracellular Signal Molecules in Regulation of the PI3K/AKT Signaling in Human Hepatoma Cell Lines. Int. J. Cancer 2010, 128, 524-532. [CrossRef] [PubMed]

76. Zhu, M.; Guo, J.; Li, W.; Lu, Y.; Fu, S.; Xie, X.; Xia, H.; Dong, X.; Chen, Y.; Quan, M.; et al. Hepatitis B Virus X Protein Induces Expression of Alpha-Fetoprotein and Activates PI3K/MTOR Signaling Pathway in Liver Cells. Oncotarget 2015, 6, 12196-12208. [CrossRef] [PubMed]

77. Xue, J.; Cao, Z.; Cheng, Y.; Wang, J.; Liu, Y.; Yang, R.; Li, H.; Jiang, W.; Li, G.; Zhao, W.; et al. Acetylation of Alpha-Fetoprotein Promotes Hepatocellular Carcinoma Progression. Cancer Lett. 2020, 471, 12-26. [CrossRef]

78. Golob-Schwarzl, N.; Krassnig, S.; Toeglhofer, A.M.; Park, Y.N.; Gogg-Kamerer, M.; Vierlinger, K.; Schröder, F.; Rhee, H.; Schicho, R.; Fickert, P.; et al. New Liver Cancer Biomarkers: PI3K/AKT/mTOR Pathway Members and Eukaryotic Translation Initiation Factors. Eur. J. Cancer 2017, 83, 56-70. [CrossRef]

79. Zhang, R.; Lin, H.-M.; Broering, R.; Shi, X.-D.; Yu, X.-H.; Xu, L.-B.; Wu, W.-R.; Liu, C. Dickkopf-1 Contributes to Hepatocellular Carcinoma Tumorigenesis by Activating the Wnt/ $\beta$-Catenin Signaling Pathway. Signal Transduct. Target. Ther. 2019, 4, 1-10. [CrossRef]

80. Fezza, M.; Moussa, M.; Aoun, R.; Haber, R.; Hilal, G. DKK1 Promotes Hepatocellular Carcinoma Inflammation, Migration and Invasion: Implication of TGF- $\beta 1$. PLoS ONE 2019, 14, e0223252. [CrossRef] 
81. Zekri, A.-R.N.; El Kassas, M.; El Salam, E.S.; Hassan, R.M.; Mohanad, M.; Gabr, R.M.; Lotfy, M.M.; Abdel-Zaher, R.A.T.; Bahnassy, A.A.; Ahmed, O.S. The Possible Role of Dickkopf-1, Golgi Protein-73 and Midkine as Predictors of Hepatocarcinogenesis: A Review and an Egyptian Study. Sci. Rep. 2020, 10, 1-11. [CrossRef]

82. Shen, Q.; Fan, J.; Yang, X.-R.; Tan, Y.; Zhao, W.; Xu, Y.; Wang, N.; Niu, Y.; Wu, Z.; Zhou, J.; et al. Serum DKK1 as a Protein Biomarker for the Diagnosis of Hepatocellular Carcinoma: A Large-Scale, Multicentre Study. Lancet Oncol. 2012, 13, 817-826. [CrossRef]

83. Liu, J.; Wang, Z.; Tang, J.; Tang, R.; Shan, X.; Zhang, W.; Chen, Q.; Zhou, F.; Chen, K.; Huang, A.; et al. Hepatitis C Virus Core Protein Activates Wnt/ $\beta$-Catenin Signaling through Multiple Regulation of Upstream Molecules in the SMMC-7721 Cell Line. Arch. Virol. 2011, 156, 1013-1023. [CrossRef]

84. Umer, M.; Qureshi, S.A.; Hashmi, Z.Y.; Raza, A.; Ahmad, J.; Rahman, M.; Iqbal, M. Promoter Hypermethylation of Wnt Pathway Inhibitors in Hepatitis C Virus-Induced Multistep Hepatocarcinogenesis. Virol. J. 2014, 11, 117. [CrossRef] [PubMed]

85. Eldeeb, M.K.; Magour, G.M.; Bedair, R.N.; Shamseya, M.M.; Hammouda, M.A. Study of Dickkopf-1 (DKK-1) in Patients with Chronic Viral Hepatitis C-Related Liver Cirrhosis with and without Hepatocellular Carcinoma. Clin. Exp. Hepatol. 2020, 6, 85-91. [CrossRef] [PubMed]

86. Essa, E.S.; Montaser, A.B.; Badawy, M.T.; Essa, A.S.; Mokhtar, M.S. DKK1 in Relation to HCV Induced Liver Cirrhosis and HCV Induced HCC Curative Resection. Acta Gastro-Enterol. Belg. 2016, 79, 309-313.

87. Qiao, Y.; Chen, J.; Li, X.; Wei, H.; Xiao, F.; Chang, L.; Zhang, R.; Hao, X.; Wei, H. Serum gp73 is Also a Biomarker for Diagnosing Cirrhosis in Population with Chronic HBV Infection. Clin. Biochem. 2014, 47, 216-222. [CrossRef]

88. Wei, M.; Xu, Z.; Pan, X.; Zhang, X.; Liu, L.; Yang, B.; Chen, Y. Serum GP73-An Additional Biochemical Marker for Liver Inflammation in Chronic HBV Infected Patients with Normal or Slightly Raised ALT. Sci. Rep. 2019, 9, 1-7. [CrossRef]

89. Xia, Y.; Zhang, Y.; Shen, M.; Xu, H.; Li, Z.; He, N. Golgi Protein 73 and Its Diagnostic Value in Liver Diseases. Cell Prolif. 2019, 52, e12538. [CrossRef] [PubMed]

90. Liu, L.; Zhu, J.; Yang, J.; Li, X.; Yuan, J.; Wu, J.; Liu, Z. GP73 Facilitates Hepatitis B Virus Replication by Repressing the NF-kappaB Signaling Pathway. J. Med. Virol. 2020, 92, 3327-3335. [CrossRef]

91. Yang, S.; Zeng, C.; Fang, X.; He, Q.; Liu, L.; Bao, S.; Pan, X.; Xiong, Z. Hepatitis B Virus Upregulates GP73 Expression by Activating the HIF-2 $\alpha$ Signaling Pathway. Oncol. Lett. 2018, 15, 5264-5270. [CrossRef]

92. Chen, Y.; Tian, Z. HBV-Induced Immune Imbalance in the Development of HCC. Front. Immunol. 2019, 10, 2048. [CrossRef]

93. Rivino, L.; Le Bert, N.; Gill, U.S.; Kunasegaran, K.; Cheng, Y.; Tan, D.Z.; Becht, E.; Hansi, N.K.; Foster, G.R.; Su, T.-H.; et al. Hepatitis B Virus-Specific T Cells Associate with Viral Control upon Nucleos(t)ide-Analogue Therapy Discontinuation. J. Clin. Investig. 2018, 128, 668-681. [CrossRef]

94. Dolgormaa, G.; Harimoto, N.; Ishii, N.; Yamanaka, T.; Hagiwara, K.; Tsukagoshi, M.; Igarashi, T.; Watanabe, A.; Kubo, N.; Araki, K.; et al. Mac-2-Binding Protein Glycan Isomer Enhances the Aggressiveness of Hepatocellular Carcinoma by Activating mTOR Signaling. Br. J. Cancer 2020, 123, 1145-1153. [CrossRef] [PubMed]

95. Kuno, A.; Ikehara, Y.; Tanaka, Y.; Ito, K.; Matsuda, A.; Sekiya, S.; Hige, S.; Sakamoto, M.; Kage, M.; Mizokami, M.; et al. A Serum "Sweet-Doughnut" Protein Facilitates Fibrosis Evaluation and Therapy Assessment in Patients with Viral Hepatitis. Sci. Rep. 2013, 3, 1065. [CrossRef] [PubMed]

96. Narimatsu, H. Development of M2BPGi: A Novel Fibrosis Serum GlyCo-biomarker for Chronic Hepatitis/Cirrhosis Diagnostics. Expert Rev. Proteom. 2015, 12, 683-693. [CrossRef] [PubMed]

97. Jekarl, D.W.; Choi, H.; Lee, S.; Kwon, J.H.; Lee, S.W.; Yu, H.; Kim, M.; Kim, Y.; Sung, P.S.; Yoon, S.K. Diagnosis of Liver Fibrosis with Wisteria Floribunda Agglutinin-Positive Mac-2 Binding Protein (WFA-M2BP) Among Chronic Hepatitis B Patients. Ann. Lab. Med. 2018, 38, 348-354. [CrossRef]

98. Jun, T.; Hsu, Y.-C.; Ogawa, S.; Huang, Y.-T.; Yeh, M.-L.; Tseng, C.-H.; Huang, C.-F.; Tai, C.-M.; Dai, C.-Y.; Huang, J.-F.; et al. Mac-2 Binding Protein Glycosylation Isomer as a Hepatocellular Carcinoma Marker in Patients with Chronic Hepatitis B or C Infection. Hepatol. Commun. 2019, 3, 493-503. [CrossRef]

99. Liu, J.; Hu, H.-H.; Lee, M.-H.; Korenaga, M.; Jen, C.-L.; Batrla-Utermann, R.; Lu, S.-N.; Wang, L.-Y.; Mizokami, M.; Chen, C.-J.; et al. Serum Levels of M2BPGi as Short-Term Predictors of Hepatocellular Carcinoma in Untreated Chronic Hepatitis B Patients. Sci. Rep. 2017, 7, 1-10. [CrossRef]

100. Mak, L.-Y.; To, W.-P.; Wong, D.K.-H.; Fung, J.; Liu, F.; Seto, W.-K.; Lai, C.-L.; Yuen, M.-F. Serum Mac-2 Binding Protein Glycosylation Isomer Level Predicts Hepatocellular Carcinoma Development in E-negative Chronic Hepatitis B Patients. World J. Gastroenterol. 2019, 25, 1398-1408. [CrossRef]

101. Hsu, Y.-C.; Jun, T.; Huang, Y.-T.; Yeh, M.-L.; Lee, C.-L.; Ogawa, S.; Cho, S.-H.; Lin, J.-T.; Yu, M.-L.; Nguyen, M.H.; et al. Serum M2BPGi Level and Risk of Hepatocellular Carcinoma after Oral Anti-viral Therapy in Patients with Chronic Hepatitis B. Aliment. Pharmacol. Ther. 2018, 48, 1128-1137. [CrossRef] [PubMed]

102. Yamasaki, K.; Tateyama, M.; Abiru, S.; Komori, A.; Nagaoka, S.; Saeki, A.; Hashimoto, S.; Sasaki, R.; Bekki, S.; Kugiyama, Y.; et al. Elevated Serum Levels of Wisteria Floribunda Agglutinin-Positive Human Mac-2 Binding Protein Predict the Development of Hepatocellular Carcinoma in Hepatitis C Patients. Hepatology 2014, 60, 1563-1570. [CrossRef] [PubMed]

103. Shirabe, K.; Bekki, Y.; Gantumur, D.; Araki, K.; Ishii, N.; Kuno, A.; Narimatsu, H.; Mizokami, M. Mac-2 Binding Protein Glycan Isomer (M2BPGI) Is a New Serum Biomarker for Assessing Liver Fibrosis: More Than a Biomarker of Liver Fibrosis. J. Gastroenterol. 2018, 53, 819-826. [CrossRef] [PubMed] 
104. Saleh, A.S.; Salama, M.M.; Alhusseini, M.M.; A Mohamed, G. M2BPGi for Assessing Liver Fibrosis in Patients with Hepatitis C Treated with Direct-Acting Antivirals. World J. Gastroenterol. 2020, 26, 2864-2876. [CrossRef] [PubMed]

105. Lupberger, J.; Zeisel, M.B.; Xiao, F.; Thumann, C.; Fofana, I.; Zona, L.; Davis, C.; Mee, C.J.; Turek, M.; Gorke, S.; et al. EGFR and EphA2 are Host Factors for Hepatitis C Virus Entry and Possible Targets for Antiviral Therapy. Nat. Med. 2011, 17, 589-595. [CrossRef] [PubMed]

106. Zona, L.; Lupberger, J.; SidAhmed-Adrar, N.; Thumann, C.; Harris, H.J.; Barnes, A.; Florentin, J.; Tawar, R.G.; Xiao, F.; Turek, M.; et al. HRas Signal Transduction Promotes Hepatitis C Virus Cell Entry by Triggering Assembly of the Host Tetraspanin Receptor Complex. Cell Host Microbe 2013, 13, 302-313. [CrossRef]

107. Mailly, L.; Xiao, F.; Lupberger, J.; Wilson, G.K.; Aubert, P.; Duong, F.H.T.; Calabrese, D.; Leboeuf, C.; Fofana, I.; Thumann, C.; et al. Clearance of Persistent Hepatitis C Virus Infection in Humanized Mice Using a Claudin-1-Targeting Monoclonal Antibody. Nat. Biotechnol. 2015, 33, 549-554. [CrossRef]

108. Roehlen, N.; Crouchet, E.; Baumert, T.F. Liver Fibrosis: Mechanistic Concepts and Therapeutic Perspectives. Cells 2020, 9 , 875. [CrossRef] [PubMed]

109. Seoane, J.; Gomis, R.R. TGF- $\beta$ Family Signaling in Tumor Suppression and Cancer Progression. Cold Spring Harb. Perspect. Biol. 2017, 9, a022277. [CrossRef] [PubMed]

110. Chusri, P.; Kumthip, K.; Hong, J.; Zhu, C.; Duan, X.; Jilg, N.; Fusco, D.N.; Brisac, C.; Schaefer, E.A.; Cai, D.; et al. HCV Induces Transforming Growth Factor $\beta 1$ through Activation of Endoplasmic Reticulum Stress and the Unfolded Protein Response. Sci. Rep. 2016, 6, 22487. [CrossRef]

111. Cheng, P.-L.; Chang, M.-H.; Chao, C.-H.; Lee, Y.-H.W. Hepatitis C Viral Proteins Interact with Smad3 and Differentially Regulate TFG- $\beta$ /Smad3-Mediated Transcriptional Activation. Oncogene 2004, 23, 7821-7838. [CrossRef]

112. Clemente, M.; Nunez, O.; Lorente, R.; Rincon, D.; Matilla, A.; Salcedo, M.; Catalina, M.V.; Ripoll, C.; Iacono, O.L.; Banares, R.; et al. Increased Intrahepatic and Circulating Levels of Endoglin, a TFG- $\beta 1$ Co-receptor, in Patients with Chronic Hepatitis C Virus Infection: Relationship to Histological and Serum Markers of Hepatic Fibrosis. J. Viral Hepat. 2006, 13, 625-632. [CrossRef]

113. Tardif, K.D.; Waris, G.; Siddiqui, A. Hepatitis C Virus, ER Stress, and Oxidative Stress. Trends Microbiol. 2005, 13, 159-163. [CrossRef]

114. Abdalla, M.Y.; Mathahs, M.M.; Ahmad, I.M. Reduced Heme Oxygenase-1 Expression in Steatotic Livers Infected with Hepatitis C Virus. Eur. J. Intern. Med. 2012, 23, 649-655. [CrossRef] [PubMed]

115. He, G.; Karin, M. NF-кB and STAT3-Key Players in Liver Inflammation and Cancer. Cell Res. 2010, 21, 159-168. [CrossRef] [PubMed]

116. Li, Y.; Zhang, Q.; Liu, Y.; Luo, Z.; Kang, L.; Qu, J.; Liu, W.; Xia, X.; Wu, K.; Wu, J. Hepatitis C Virus Activates Bcl-2 and MMP-2 Expression through Multiple Cellular Signaling Pathways. J. Virol. 2012, 86, 12531-12543. [CrossRef]

117. Abdel-Latif, M.S. Plasma Levels of Matrix Metalloproteinase (MMP)-2, MMP-9 and Tumor Necrosis Factor- $\alpha$ in Chronic Hepatitis C Virus Patients. Open Microbiol. J. 2015, 9, 136-140. [CrossRef]

118. Wilson, G.K.; Brimacombe, C.L.; Rowe, I.A.; Reynolds, G.M.; Fletcher, N.F.; Stamataki, Z.; Bhogal, R.H.; Simões, M.L.; Ashcroft, M.; Afford, S.C.; et al. A Dual Role for Hypoxia Inducible Factor- $1 \alpha$ in the Hepatitis C Virus Lifecycle and Hepatoma Migration. J. Hepatol. 2012, 56, 803-809. [CrossRef] [PubMed]

119. Mas, V.R.; Maluf, D.G.; Archer, K.J.; Yanek, K.C.; Fisher, R.A. Angiogenesis Soluble Factors as Hepatocellular Carcinoma Noninvasive Markers for Monitoring Hepatitis C Virus Cirrhotic Patients Awaiting Liver Transplantation. Transplantation 2007, 84, 1262-1271. [CrossRef] [PubMed]

120. Hernández-Bartolomé, Á; López-Rodríguez, R.; Borque, M.J.; González-Moreno, L.; Real-Martínez, Y.; García-Buey, L.; MorenoOtero, R.; Sanz-Cameno, P. Angiopoietin-2/Angiopoietin-1 as Non-invasive Biomarker of Cirrhosis in Chronic Hepatitis C. World J. Gastroenterol. 2016, 22, 9744-9751. [CrossRef]

121. Hernández-Bartolomé, Á.; López-Rodríguez, R.; García-Buey, L.; Martín-Vílchez, S.; Rodríguez-Muñoz, Y.; Borque, M.J.; GonzálezMoreno, L.; Real-Martínez, Y.; Mendoza-Ridruejo, J.; Martín-Pérez, E.; et al. Intrahepatic Angiopoietin-2 Correlates with Chronic Hepatitis C Progression and Is Induced in Hepatitis C Virus Replicon Systems. Liver Int. 2016, 37, 1148-1156. [CrossRef]

122. Benkheil, M.; Van Haele, M.; Roskams, T.; Laporte, M.; Noppen, S.; Abbasi, K.; Delang, L.; Neyts, J.; Liekens, S. CCL20, A Direct-Acting Pro-angiogenic Chemokine Induced by Hepatitis C Virus (HCV): Potential Role in HCV-Related Liver Cancer. Exp. Cell Res. 2018, 372, 168-177. [CrossRef]

123. Soliman, H.H.; Nagy, H.; Kotb, N.; El-Din, M.A.A. The Role of Chemokine CC Ligand 20 in Patients with Liver Cirrhosis and Hepatocellular Carcinoma. Int. J. Biol. Markers 2012, 27, 125-131. [CrossRef]

124. Oliveira, D.A.R.; Castanhole-Nunes, M.M.; Biselli-Chicote, P.M.; Pavarino, É.C.; da Silva, R.C.M.A.; Da Silva, R.F.; Goloni-Bertollo, E.M. Differential Expression of Angiogenesis-Related miRNAs and VEGFA in Cirrhosis and Hepatocellular Carcinoma. Arch. Med. Sci. 2020, 16, 1150-1157. [CrossRef]

125. Salum, G.M.; El Din, N.G.B.; Ibrahim, M.K.; Anany, M.A.; Dawood, R.M.; Khairy, A.; El Awady, M.K. Vascular Endothelial Growth Factor Expression in Hepatitis C Virus-Induced Liver Fibrosis: A Potential Biomarker. J. Interf. Cytokine Res. 2017, 37, 310-316. [CrossRef]

126. Zhu, C.L.; Li, W.T.; Li, Y.; Gao, R.T. Serum Levels of Tissue Inhibitor of Metalloproteinase-1 Are Correlated with Liver Fibrosis in Patients with Chronic Hepatitis B. J. Dig. Dis. 2012, 13, 558-563. [CrossRef] 
127. Seven, G.; Karatayli, S.C.; Kose, S.K.; Yakut, M.; Kabacam, G.; Toruner, M.; Heper, A.O.; Voelker, M.; Erden, E.; Bozdayi, A.M.; et al. Serum Connective Tissue Markers as Predictors of Advanced Fibrosis in Patients with Chronic Hepatitis B and D. Turk. J. Gastroenterol. 2011, 22, 305-314. [CrossRef]

128. Xue, Y.; Mars, W.M.; Bowen, W.; Singhi, A.D.; Stoops, J.; Michalopoulos, G.K. Hepatitis C Virus Mimics Effects of Glypican-3 on CD81 and Promotes Development of Hepatocellular Carcinomas via Activation of Hippo Pathway in Hepatocytes. Am. J. Pathol. 2018, 188, 1469-1477. [CrossRef] [PubMed]

129. Shimizu, Y.; Mizuno, S.; Fujinami, N.; Suzuki, T.; Saito, K.; Konishi, M.; Takahashi, S.; Gotohda, N.; Tada, T.; Toyoda, H.; et al. Plasma and Tumoral Glypican-3 Levels Are Correlated in Patients with Hepatitis C Virus-Related Hepatocellular Carcinoma. Cancer Sci. 2019, 111, 334-342. [CrossRef]

130. Jaenisch, R.; Bird, A. Epigenetic Regulation of Gene Expression: How the Genome Integrates Intrinsic and Environmental Signals. Nat. Genet. 2003, 33, 245-254. [CrossRef] [PubMed]

131. Hardy, T.; Mann, A.D. Epigenetics in Liver Disease: From Biology to Therapeutics. Gut 2016, 65, 1895-1905. [CrossRef] [PubMed]

132. Moran-Salvador, E.; Mann, J. Epigenetics and Liver Fibrosis. Cell. Mol. Gastroenterol. Hepatol. 2017, 4, 125-134. [CrossRef]

133. Wilson, C.L.; Mann, D.A.; Borthwick, L.A. Epigenetic Reprogramming in Liver Fibrosis and Cancer. Adv. Drug Deliv. Rev. 2017, 121, 124-132. [CrossRef]

134. Zhang, Y.; Petropoulos, S.; Liu, J.; Cheishvili, D.; Zhou, R.; Dymov, S.; Li, K.; Li, N.; Szyf, M. The Signature of Liver Cancer in Immune Cells DNA Methylation. Clin. Epigenetics 2018, 10, 8. [CrossRef]

135. Li, K.; Qin, L.; Jiang, S.; Zhang, C.; Liu, G.; Sun, J.; Sun, H.; Zhao, Y.; Li, N.; Zhang, Y.; et al. The Signature of HBV-Related Liver Disease in Peripheral Blood Mononuclear Cell DNA Methylation. Clin. Epigenetics 2020, 12, 1-13. [CrossRef]

136. Vivekanandan, P.; Daniel, H.D.-J.; Kannangai, R.; Martinez-Murillo, F.; Torbenson, M. Hepatitis B Virus Replication Induces Methylation of both Host and Viral DNA. J. Virol. 2010, 84, 4321-4329. [CrossRef]

137. Ancey, P.-B.; Testoni, B.; Gruffaz, M.; Cros, M.-P.; Durand, G.; Le Calvez-Kelm, F.; Durantel, D.; Herceg, Z.; Hernandez-Vargas, H. Genomic Responses to Hepatitis B Virus (HBV) Infection in Primary Human Hepatocytes. Oncotarget 2015, 6, 44877-44891. [CrossRef]

138. Dong, X.; Hou, Q.; Chen, Y.; Wang, X. Diagnostic Value of the Methylation of Multiple Gene Promoters in Serum in Hepatitis B Virus-Related Hepatocellular Carcinoma. Dis. Markers 2017, 2017, 1-6. [CrossRef]

139. Wei, L.; Huang, Y.; Zhao, R.; Zhang, J.; Liu, Q.; Liang, W.; Ding, X.; Gao, B.; Li, B.; Sun, C.; et al. Detection of Promoter Methylation Status of Suppressor of Cytokine Signaling 3 (SOCS3) in Tissue and Plasma from Chinese Patients with Different Hepatic Diseases. Clin. Exp. Med. 2018, 18, 79-87. [CrossRef]

140. Wu, H.-C.; Yang, H.-I.; Wang, Q.; Chen, C.-J.; Santella, R.M. Plasma DNA Methylation Marker and Hepatocellular Carcinoma Risk Prediction Model for the General Population. Carcinogenesis 2017, 38, 1021-1028. [CrossRef]

141. Hamdane, N.; Jühling, F.; Crouchet, E.; El Saghire, H.; Thumann, C.; Oudot, M.A.; Bandiera, S.; Saviano, A.; Ponsolles, C.; Suarez, A.A.R.; et al. HCV-Induced Epigenetic Changes Associated with Liver Cancer Risk Persist After Sustained Virologic Response. Gastroenterology 2019, 156, 2313-2329.e7. [CrossRef]

142. Juhling, F.; Hamdane, N.; Crouchet, E.; Li, S.; El Saghire, H.; Mukherji, A.; Fujiwara, N.; Oudot, M.A.; Thumann, C.; Saviano, A.; et al. Targeting Clinical Epigenetic Reprogramming for Chemoprevention of Metabolic and Viral Hepatocellular Carcinoma. Gut 2020, 70, 157-169. [CrossRef]

143. Perez, S.; Kaspi, A.; Domovitz, T.; Davidovich, A.; Lavi-Itzkovitz, A.; Meirson, T.; Holmes, J.A.; Dai, C.-Y.; Huang, C.-F.; Chung, R.T.; et al. Hepatitis C Virus Leaves an Epigenetic Signature Post Cure of Infection by Direct-Acting Antivirals. PLoS Genet. 2019, 15, e1008181. [CrossRef] [PubMed]

144. Shaker, O.G.; Senousy, M.A. Serum microRNAs as Predictors for Liver Fibrosis Staging in Hepatitis C Virus-Associated Chronic Liver Disease Patients. J. Viral Hepat. 2017, 24, 636-644. [CrossRef]

145. Wang, X.; He, Y.; Mackowiak, B.; Gao, B. MicroRNAs as Regulators, Biomarkers and Therapeutic Targets in Liver Diseases. Gut 2020, 10, 1136. [CrossRef]

146. Thietart, S.; Rautou, P.-E. Extracellular Vesicles as Biomarkers in Liver Diseases: A Clinician's Point of View. J. Hepatol. 2020, 73, 1507-1525. [CrossRef]

147. Matsuura, K.; De Giorgi, V.; Schechterly, C.; Wang, R.Y.; Farci, P.; Tanaka, Y.; Alter, H.J. Circulating Let-7 Levels in Plasma and Extracellular Vesicles Correlate with Hepatic Fibrosis Progression in Chronic Hepatitis C. Hepatology 2016, 64, 732-745. [CrossRef]

148. Rattan, P.; Minacapelli, C.D.; Rustgi, V. The Microbiome and Hepatocellular Carcinoma. Liver Transplant. 2020, $26,1316-1327$. [CrossRef]

149. Yu, L.-X.; Schwabe, L.-X.Y.R.F. The Gut Microbiome and Liver Cancer: Mechanisms and Clinical Translation. Nat. Rev. Gastroenterol. Hepatol. 2017, 14, 527-539. [CrossRef]

150. Hoshida, Y.; Nijman, S.M.; Kobayashi, M.; Chan, J.A.; Brunet, J.-P.; Chiang, D.Y.; Villanueva, A.; Newell, P.; Ikeda, K.; Hashimoto, M.; et al. Integrative Transcriptome Analysis Reveals Common Molecular Subclasses of Human Hepatocellular Carcinoma. Cancer Res. 2009, 69, 7385-7392. [CrossRef]

151. Guichard, C.; Amaddeo, G.; Imbeaud, S.; Ladeiro, Y.; Pelletier, L.; Ben Maad, I.; Calderaro, J.; Bioulac-Sage, P.; Letexier, M.; Degos, F.; et al. Integrated Analysis of Somatic Mutations and Focal Copy-Number Changes Identifies Key Genes and Pathways in Hepatocellular Carcinoma. Nat. Genet. 2012, 44, 694-698. [CrossRef] 
152. Schulze, K.; Imbeaud, S.; Letouzé, E.; Alexandrov, L.B.; Calderaro, J.; Rebouissou, S.; Couchy, G.; Meiller, C.; Shinde, J.; Soysouvanh, F.; et al. Exome Sequencing of Hepatocellular Carcinomas Identifies New Mutational Signatures and Potential Therapeutic Targets. Nat. Genet. 2015, 47, 505-511. [CrossRef]

153. Sengupta, S.; Parikh, N.D. Biomarker Development for Hepatocellular Carcinoma Early Detection: Current and Future Perspectives. Hepatic Oncol. 2017, 4, 111-122. [CrossRef]

154. Saad, Y.; El-Serafy, M.; Eldin, M.S.; Abdellatif, Z.; Khatab, H.; Elbaz, T.; Elgarem, H. New Genetic Markers for Diagnosis of Hepatitis C Related Hepatocellular Carcinoma in Egyptian Patients. J. Gastrointest. Liver Dis. 2013, 22, 419-425.

155. Hodeib, H.; Elshora, O.; Selim, A.; Sabry, N.M.; El-Ashry, H.M. Serum Midkine and Osteopontin Levels as Diagnostic Biomarkers of Hepatocellular Carcinoma. Electron. Physician 2017, 9, 3492-3498. [CrossRef] [PubMed]

156. Sobhy, A.M.M.F.; Azeem, A.H.; Ashmawy, A.M.; Khalifa, H.O. Significance of Biglycan and Osteopontin as Non-invasive Markers of Liver Fibrosis in Patients with Chronic Hepatitis B Virus and Chronic Hepatitis C Virus. J. Investig. Med. 2018, 67, 681-685. [CrossRef] [PubMed]

157. Zhu, M.; Zheng, J.; Wu, F.; Kang, B.; Liang, J.; Heskia, F.; Zhang, X.; Shan, Y. OPN is a Promising Serological Biomarker for Hepatocellular Carcinoma Diagnosis. J. Med. Virol. 2020, 92, 3596-3603. [CrossRef] [PubMed]

158. Kolgelier, S.; Demir, N.A.; Inkaya, A.C.; Sumer, S.; Ozcimen, S.; Demir, L.S.; Pehlivan, F.S.; Arslan, M.; Arpaci, A. Serum Levels of Annexin A2 as a Candidate Biomarker for Hepatic Fibrosis in Patients with Chronic Hepatitis B. Hepat. Mon. 2015, 15, e30655. [CrossRef] [PubMed]

159. Tang, L.; Liu, J.-X.; Zhang, Z.-J.; Xu, C.-Z.; Zhang, X.-N.; Huang, W.-R.; Zhou, D.-H.; Wang, R.-R.; Chen, X.-D.; Xiao, M.-B.; et al. High Expression of Anxa2 and Stat3 Promote Progression of Hepatocellular Carcinoma and Predict Poor Prognosis. Pathol. Res. Pr. 2019, 215, 152386. [CrossRef] [PubMed]

160. Ali, L.H.; Higazi, A.M.; Moness, H.M.; Farag, N.M.; Saad, Z.M.; Moukareb, A.H.; Soliman, W.; El Sagheer, G.; El Hamid, S.R.A.; Hamid, H.A. Clinical Significances and Diagnostic Utilities of Both miR-215 and Squamous Cell Carcinoma Antigen-IgM versus Alpha-Fetoprotein in Egyptian Patients with Hepatitis C Virus-Induced Hepatocellular Carcinoma. Clin. Exp. Gastroenterol. 2019, 12, 51-66. [CrossRef]

161. Gallotta, A.; Paneghetti, L.; Mrázová, V.; Bednárová, A.; Kružlicová, D.; Frecer, V.; Miertus, S.; Biasiolo, A.; Martini, A.; Pontisso, P.; et al. Development of a Novel Diagnostic Algorithm to Predict NASH in HCV-Positive Patients. Int. J. Biol. Markers 2018, 33, 231-236. [CrossRef] 